Jpn. J. Med. Mycol.

Vol. 41, 157-160, 2000

ISSN 0916-4804

総説

\author{
アトピー性皮膚炎と真菌アレルギー \\ 照井 正 ${ }^{1}$ 牧 野 好 夫 $^{2}$ 岡 田 美喜子 ${ }^{1}$ \\ 橋本彰 ${ }^{1}$ 田上八 朗 ${ }^{1}$ \\ 1 東北大学大学院医学系研究科内科病態学講座皮膚科分野 \\ 2 仙台市
}

\begin{abstract}
要旨
アトピー性皮膚炎の発症には様々な要因が絡んでいる.たとえば, 非アレルギー要因としてバリアー機能の他，心 理的要因や接触皮膚炎, 物理的外力による刺激因子などがある。また, 本稿で説明をしたようにアレルギー要因を考 えた場合も, それぞれの患者が関わるアレルギータイプに差があり, また, 悪化因子としてのアレルゲンの種類やそ の数も患者間で著明な差異がある. 空中浮遊抗原のダニが重要なアレルゲンのひとつであるが, 細菌の他, ここで述 ベたように皮膚に常在する真菌が $\mathrm{AD}$ の修飾因子として働いている可能性を示した. さらに，アレルゲンの進入経路 の違いにより,アレルギーの反応様式に差異があることを示した. AD の pathogenesis や発症や悪化の予防を考える 上で重要であると考えた.
\end{abstract}

Key words：アトピー性皮膚炎 (atopic dermatitis), 真菌アレルギー (fungal allergy), カンジダ (Candida), マ ラセチア (Malassezia), 白㿏 (Trichophyton)

\section{はじめに}

真菌が関係する皮膚疾患は大きく二つのグループに分 けられる．1）真菌が感染源となり，病原性を発揮する ことにより発症する皮膚真菌症と，2）すでに存在する 皮膚疾患に真菌が修飾因子として働く場合である.二つ の目のグループに入る代表的皮膚疾患としてアトピー性 皮膚炎（AD）や脂漏性皮膚炎，乾癬が上げられる。今 回の話題の中心は, 真菌アレルギーの関与と抗真菌剤の 有効性が報告されている $\mathrm{AD}$ である.

\section{アトピー性皮膚炎について}

\section{1 ）アトピー性皮膚炎（AD）の診断}

喘息や鼻炎を含めたアトピー性疾患の診断条件として， 1）患者血清中に原因となるアレルゲンに対するレアギ ン（IgE）が存在し，2）このアレルゲンの投与で症状を 惹起できることが上げられる ${ }^{1)}$. AD は 1935 年 Hills と Sulzberger ${ }^{2)}$ によって命名された皮膚疾患で，アトピー 性疾患 (喘息, 枯草熱) を高率に合併し, 軽快と悪化を 繰り返す湿疹病変を示すと報告された。しかし，ADで は皮膚テストが高率に陽性を示すが，陽性となる抗原を 投与しても悪化する例が少ないことが分かってきた ${ }^{3)}$. このように，皮膚反応を起こす原因アレルゲンを投与し ても皮膚炎が再現されないため，アトピー性皮膚炎はア

別刷請求先 : 照井 正

干 980-8574 仙台市青葉区星陵町 1-1

東北大学大学院医学系研究科内科病態学講座 皮膚科分野
トピー疾患でないとの反論があった ${ }^{4)}$. 以後，この点は 解決されないまま今日にいたっているといってよい.

日本皮膚科学会の示した $\mathrm{AD} の$ 診断基準 5)の要点は, 1）増悪・寛解を繰り返し，2）かゆみのある湿疹を主病 変とする疾患であり，3）患者の多くはアトピー素因を 持つことであり，4）他の鑑別すべき疾患を除外するこ とにある．また，年齢により皮疹の好発部位が異なるの で特徵的な皮疹の分布を考慮して診断している.Coca の提案したアトピー疾患の診断条件では，アレルゲンに よる皮疹の再現性について触れられているが，日本皮膚 科学会で提案した $\mathrm{AD}$ 診断基準では言及されていない. このような基準は簡便で，一般診療に役に立つ一方で,

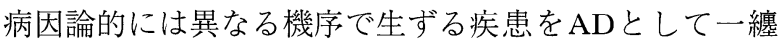
めにしている可能性が否めないため，この診断基準のも とに集められた臨床研究データを解析する時には注意を 払う必要がある。

\section{2) $\mathrm{AD} の$ heterogeneity}

$\mathrm{AD}$ の発症に関係する $\mathrm{T}$ helper（Th）細胞として, 互 いに抑制的に働くTh1 と Th2の二つが上げられる.Th 2 細胞は IgEの産生に関与する IL-4 と好酸球の増殖と 機能に関与する IL-5 を産生し, Th 1 は細胞性免疫や腫 瘍免疫に関与する IFN $\gamma$ を放出する. AD 患者の病変部 や末梢血中では, Th2 細胞が Th 1 細胞よりも優位であ ることが多くの研究者によって報告されている6,7). 最 近, AD 患者のアレルゲン貼布試験部位を急性期と慢性 期に分けて経時的に生検した興味深い実験結果が報告さ れている ${ }^{8)}$. その結果, 急性期の病変では Th 2 細胞が優 位を占めるが, 慢性期の病変では Th 1 が関与していた。 
このように，皮疹の stageによって関与する Thのタイ プが異なることが明らかにされた。

上述したように $\mathrm{AD}$ の臨床症状やその経過は患者によ って様々であり, その発症期序は単純ではない. ADの 発症要因として，アレルギー要因の他にバリアー異常な どの非アレルギー要因を考慮する必要があり, 個々の症 例を調べると，これら二つの要因の関与する割合は患者 間でまちまちである. また，アレルギー性要因の強い患 者間でも, 発症や増悪にかかわるアレルゲンの種類は患 者によって異なり, 同じ患者でも加齢とともに特異 IgE の種類が変化する.さらに, アレルゲンに対するアレル ギー反応の様式も異なることが分かってきた.

これまで, $\mathrm{AD}$ 発症に関与するアレルゲン検索法と して以下の二つの皮膚テストが行われてきた. 第一に， 肥満細胞状の IgEがアレルゲンによって架橋されること によって生ずる即時型反応 (immediate reaction, IMR) で, 第二は, $\mathrm{T}$ 細胞による細胞性免疫を介する遅延型反 応 (delayed type hypersensitivity, DTH) である. IMR はアレルゲン曝露後 30 分前後で惹起され, DTH は 24 〜 48 時間後を peakに引き起こされる反応である. 以前 から，喘息やアレルギー性鼻炎では，IMRに引き続いて アレルゲン曝露後 6〜12 時間後に生じる反応が観察さ れ, 遅発型反応 (late phase reaction, LPR) と呼ばれ てきた.この LPR は AD 患者でも観察され, 好酸球と Th2 が関与した反応が指摘されている. 私たちの研究で も, ダニ特異 $\operatorname{IgE}$ をつ $\mathrm{AD}$ 患者で調べてみると, 全例 でダニのプリックテスト部位にIMRがみられたが，そ の同じ部位を 8 時間後に観察すると LPR が約半数で認 められた 7 )。これらの患者の末梢血単核球にダ二抗原を 加えて培養し, その上清中のリンフォカインを調べた結 果, LPR は好酸球の増殖や機能高進させる IL-5 の産生 と相関し，LPRのみられない患者では IL-5 の産生が低 下していることが分かった.このように, アレルギー要 因の関与が示唆される $\mathrm{AD}$ 患者でも, そのアレルギー反 応様式は heterogeneousであり, 個々の病例毎に検討す べきであり，それぞれのアレルギー反応にあった治療法 を選択する時代がまもなくやってくると考えられる.

\section{3 ) $\mathrm{AD}$ と $\operatorname{IgE}$}

本症では, 皮膚炎の重症度とほぼ並行して血清 $\operatorname{IgE}$ 值 が上昇し，かつ，多種類に及ぶ傾向にある ${ }^{9)}$. とくに，気 道アトピーを合併した症例で高值を示すことが報告され ている10).一方で, 田中らによれば大阪のアトピー疾患 のない小学生 1360 人におけるダニのスコアが 2 以上の 陽性率は $30 \%$ あると報告している ${ }^{11)}$. さらに, アトピー 性疾患の既往のない正常人の血清 $\operatorname{IgE}$ 值を調べた報告に よると,アトピー疾患の症状を呈さなくても総 $\operatorname{IgE}$ 值が 高かったり, ダ二特異 IgEが異常值を示す正常人がいる ことが分かった12,13,15)。このように，IgE 検査はあくま で screening 検査であり, その結果は, 気道アトピーの有 無や臨床経過を十分考慮して判断されるべきである．日 常の診療において，すべての症例で責任抗原を決定する ことは困難であるが, 重症例や多剂抵抗性の $\mathrm{AD}$ 患者で
はできるかぎりの検索が必要である.

\section{アトピー性皮膚炎と真菌}

以前より, $\mathrm{AD}$ 患者, とくに重症の $\mathrm{AD}$ 患者血清中に カンジダやマラセチアに対する特異 $\operatorname{IgE}$ が検出され, 一 部の症例で抗真菌剂の投与が効果を示すことから，その 発症や悪化に真菌アレルギーが関与することが指摘され てきた. 以下に, 真菌, 特にカンジダやマラセチア, 白 癬と ADの関係について概説する.

\section{1) $\mathrm{AD}$ とカンジダ}

$\mathrm{AD}$ 患者でアレルゲン特異 $\operatorname{IgE}$ が異常值を示す例が多 いが，患者の年齢によって特異 IgE の種類や皮膚反応が 変化することが分かっている.すなわち, 小児では牛乳 や卵，大豆などの食物抗原に対する特異 $\operatorname{IgE}$ が陽性にな ることが多いが，3歳前後で低下し（outgrow），それ以 降は年齢を経るにしたがって，家埃中に含まれるダニや 真菌に対する陽性例が増してくることが知られている. 私たちの教室でも, 乳幼児と成人の $\mathrm{AD}$ 患者間でカンジ ダに対するIMR と DTHには違いがあることを報告し ている.すなわち，ほとんどの乳幼児例では IMR を示 さず，DTHのみみられるが7)，成人型では RAST が高 く，皮膚テストでも IMR 陽性者の数が増加し，反対に DTH の陽性率は低下する ${ }^{13,14)}$. さらに, 成人型 $\mathrm{AD} の$ カンジダに対するリンパ球幼若化反応も健常人コントロー ルに比較して低下していることを報告している13).

Tanaka らのデータ13) を見直してみると, 気道アレル ギーを合併していない $\mathrm{AD}$ 患者 (pure AD) に比較して 気道アレルギーを合併した AD 患者で総 $\mathrm{IgE}$ 值とダニな どの空中浮遊抗原に対する特異 $\operatorname{IgE}$ 值が高い值を示すが, 皮膚に接触する，あるいは，感染する機会のある抗原に 対する特異 $\operatorname{IgE}$ 值はむしろ pure $\mathrm{AD} て ゙$ 高いことが分か る.さらに, $\mathrm{AD}$ を合併しない気道アレルギー患者では カンジダ特異 $\operatorname{IgE}$ が高值を示す症例は少なく, DTH も 正常人と同じ程度であり 13$)$ ，カンジダに対する異常は $\mathrm{AD}$ に特徴的な変化であることが分かった.このように， 抗原の進入経路によって反応様式が時間的に質的に異な ることが類推され，ADの発症予防に重要な示唆を与え ると考える。

\section{2) AD とマラセチア}

マラセチアは好脂質性の真菌であり, 常在真菌叢のひ とつである。ほぼ全身に分布するが，顔面や珵部，被髪 頭部, 上背部などの脂漏部位に多く分布し, マラセチア の菌数は, 皮脂の分泌と平行して年齢とともに変化する. また，マラセチアは皮膚に種々の炎症免疫反応を引き起 こすことが知られている ${ }^{16)}$. マラセチアと ADの関係を 調べると，難治な成人型 $\mathrm{AD}$ 患者では，本菌が高頻度で 分布する顔面や䅡部に治療に抵抗する皮膚炎が生じ，特 異 $\operatorname{IgE}$ 值も高值を呈する. 本菌に対する特異 $\operatorname{IgE}$ 抗体価 は 10 歳以上で上昇し始め, 総 $\mathrm{IgE}$ 值や $\mathrm{AD}$ の重症度と 相関するとされる17). マラセチアの抗原は多様な分子量 からなる糖タンパクであり，一部カンジダ抗原と交差性 を示すと言わ机が ${ }^{18)}, \mathrm{AD}$ 患者の病変からマラセチア 
の集落数が多く分離され，マラセチアが ADの悪化因子 として関係していることが示唆されており ${ }^{19)}$, 難治な症 例では抗真菌剤の外用や内服を考慮する必要がある。

\section{3 ) AD と白癬}

$\mathrm{AD}$ と白癬の関係を調べた報告はみあたらないので,

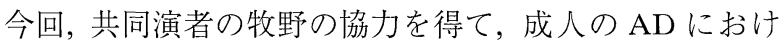
る足白撚感染率とその病型について統計的に観察した。 平成元年から平成 10 年までの 10 年間, 牧野医院を受診 した AD 患者 893 例を対照とした. 足白癬を発症した例 は 30 例で, 総 $\mathrm{AD}$ 患者の $3.4 \%$ で観察された。成人の足 白癬患者との比較を行うことはできなかったが， $\mathrm{AD}$ 患 者における足白癬の罹患率は低い数字であると思われる. また，牧野は ADでない足白癬患者を比べて，AD患者 の趾間が開大していることをその要因の一つと想定して いる. また，真菌学的検査の結果は，足白癬患者 30 例中， 18 例でT. rubrum が，8 例で T. mentagrophytes が検出さ れた. 症例数が十分でないが, 足白癬のタイプで真菌の 片寄りはみられなかった。

$\mathrm{AD}$ 患者にみられた足白癬の病型は，指間型が 16 例， 小水疱型は 1 例で, 角質増殖型は認められなかった。 た，小水疮を形成せず，軽い鱗屑のみで角質増殖型の範 疇に入らない鱗屑型（仮称）と呼ぶべき症例が18例あっ た. 我々の行った足白痒患者の自然歴の調査では，青年 期には水疮型足白癬でも，壮年期から老年期にかけて水 疮形成は稀になり，鱗屑型になることが多く観察される ことが分かった (未発表)。また，明らかな証拠はない が，鱗首型の足白癬を合併した $\mathrm{AD} の$ 免疫学的背景が, 壮年から老年期の正常人に共通するのではないかと推察 することもできる.

上記研究とは別に, 東北大学皮膚科を受診した $\mathrm{AD}$ 患 者 41 人と足白廨患者 17 人で血清中のトリコフィチン特 異 IgE を検索した. その結果, 足白廨患者とコントロー ルの健常人 12 人でトリコフィチン特異 $\operatorname{IgE}$ は検出され なかったが， $\mathrm{AD}$ 患者では足白癬の既往がないにも拘わ らず 12 人で検出された。このように，明らかな感染がな くても，白癬菌が環境抗原の一つとして $\mathrm{AD}$ 患者に浸入 し，Th2 型の反応が成立していると考えられた，AD患 者に合併してみられる足白癬は，Th1 が関与した水疮型 ではなく，Th2が優位のため，Th 1 機能の相対的な低下 が関与すると考えられる鱗屑型が多いことを部分的に説 明する所見と考えた。

\section{バリアーの破壊と蛋白抗原の侵入}

$\mathrm{AD}$ 患者の健常皮膚のバリアー機能は低下している ${ }^{20)}$. このバリアー異常が先天的であるか, あるいは, すでに 存在する subclinical な皮膚炎に基づくものかは，まだ， 結論がでていない. 何れにしろ,バリアーの異常で, 正 常の皮膚では通過しない分子量の大きい蛋白抗原が繰り 返し皮虐に浸入していると推察される. Spergelら ${ }^{21)} は$, マウス皮膚に繰り返し卵抗原を塗布すると, ADに類似 したTh2 と Th1 サイトカインがともに存在するような 皮膚炎を惹起することができたと報告している。このよ
うな動物モデルの解析を通して, $\mathrm{AD}$ 発症機序がさらに 明らかになることを期待したい.

\section{文献}

1) Coca AF: Principles of diagnosis and treatment of allergic diseases. J Am Med Assoc 97 : 1201-1203, 1931.

2) Hills LW, Sulzberger MB : Evolution of atopic dermatitis. Arch Dermatol Syphilol 32:451-463, 1935.

3) Sulzberger MB, Goodman J: The relative importance of specific skin hypersensitivity in adult atopic dermatitis. J Am Med Assoc 106 : 1000-1003, 1936.

4) Cooke RA : A consideration of some allergic problems. I. Allergic dermatitis (Eczema). J Allergy $15: 203-211$, 1944.

5）荒田次郎: アトピー性皮膚炎のトピックスー病態から治 療までーI 診断基準. 皮膚臨床 40（特集 38）：910-912, 1998.

6) Nakagawa $\mathrm{S}$, Aiba $\mathrm{S}$, Tagami $\mathrm{H}$ : Decreased frequency of interferon- $\gamma$-producing $\mathrm{CD}^{+}{ }^{+}$cells in the peripheral blood of patients with atopic dermatitis. Exp Dermatol $7: 112-118,1998$.

7) Okada M, Terui T, Honda M, Tanaka M, Chikama R, Tabata N, Tagami H: Cutaneous late phase reaction in adult atopic dermatitis patients with high serum IgE antibody to Dermatophagoides farinae: Correlation with IL-5 production by allergen-stimulated PBMC. (Submitted).

8) Thepen T, Langeveld-Wildschut EG, Bihari IC, van Wichen DF, van Reijsen FC, Mudde GC, BruijnzeelKoomen CA : Biphasic response against aeroallergen in atopic dermatitis showing a switch from an initial TH2 response to a TH1 response in situ: an immunocytochemical study. J Allergy Clin Immunol 97 : 828-837, 1996.

9) Furue $\mathrm{M}$ : Atopic dermatitis-immunological abnormality and its background. J Dermatol Sci $7: 159-168,1994$.

10）上原正巳:アトピー性皮膚炎のトピックスー病態から治 療までーIアトピー性皮膚炎とは. 皮膚臨床 40 （特集 38) : 866-869, 1998.

11）田中隆信, 中村洋之, 平塚友子, 田辺 操, 常俊義三: 学 童の呼吸器症状別にみた血清 $\operatorname{IgE}$ 值. 厚生の指標 $37: 9$ -14. 1990.

12）高松由佳, 竹原和彦, 高村利治, 橋本环磨: 医学部学生に 扔ける特異 $\operatorname{IgE}$ 抗体の検討. 日皮会誌 108 : 953-958, 1998.

13) Tanaka M, Aiba S, Takahashi K, Tagami H:Reduced proliferative responses of peripheral blood mononuclear cells specifically to Candida albicans antigen in patients with atopic dermatitis -Comparison with their normal reactivity to bacterial superantigens. Arch Dermatol Res 288 : 495-499, 1996.

14) Matsumura N, Aiba S, Tanaka M, Aoyama H, Tabata N, Tamura G, Tagami H:Comparison of immune reactivity profiles against various environmental allergens between adult patients with atopic dermatitis and patients with allergic respiratory diseases. Acta Derm Venereol (Stockh) 77 : 388-391, 1997.

15) Tanaka M, Aiba S, Matsumura N, Aoyama H, Tabata N, Sekita Y, Tagami H : IgE-mediated hypersensitivity and contact sensitivity to multiple environmental 
allergens in atopic dermatitis. Arch Dermatol $130: 1393$ $-1401,1994$.

16）照井 正, 工藤和浩, 田上八朗 : Malassezia furfur の引き 起こす皮膚の炎症・免疫反応. 真菌誌 40 : 63-67，1999.

17) Kieffer M, Bergbrant I-M, Faegermann J, Jernic GBF, Ottevanger V, Skov PS, Svejgaard E : Immune reactions to Pityrosporum ovale in adult patients with atopic and seborrheic dermatitis. J Am Acad Dermatol 22 : 723742, 1990

18) Savolainen J, Broberg A : Crossreacting IgE antibodies to Pityrosporum ovale and Candida albicans in atopic children. Clin Exp Allergy $22: 469-474,1992$.

19）比留間政太郎, 孟 杜在, 小林美保子, 須藤 一, 小川秀 興 : 真菌とアトピー性皮膚炎. 真菌誌 $40:$ 79-83，1999.

20) Watanabe M, Tagami H, Horii I, Takahashi M, Kligman AM : Functional analysis of the superficial stratum corneum in atopic eczema. Arch Dermatol $127:$ 1689-1692, 1991.

21) Spergel JM, Mizoguchi E, Oettgen H, Bhan AK, Geha RS : Roles of TH1 and $\mathrm{TH} 2$ cytokines in a murine model of allergy. J Clin Invest 103: 1103-1111, 1999.

\title{
Learning from Fungus Allergy in Atopic Dermatitis Patients
}

\author{
Tadashi Terui ${ }^{1}$, Yoshio Makino², Akira Hashimoto', \\ Mikiko Okada ${ }^{1}$, Hachiro Tagami ${ }^{1}$ \\ ${ }^{1}$ Department of Dermatology, Tohoku University School of Medicine, \\ Seiryo-machi 1-1, Sendai 980-8574, Japan \\ ${ }^{2}$ Sendai
}

It has been recognized that there are considerable variations in their skin reactivity to environmental allergens as well as in immunoreactivities, even in AD patients with similar signs and symptoms. Some $\mathrm{AD}$ patients have high serum IgE antibody levels, while others show low levels. There are also differences in the kinds of triggering factors that are related to the development and maintenance of AD, e.g., allergic or non-allergic. Even among AD patients with high titers of serum IgE antibodies, the kinds and number of allergens involved in the exacerbation of $\mathrm{AD}$ are different and can change with time. The types of the underlying allergic reactions vary as well, i.e., some show immediate reactions, while others show delayed type hypersensitivity responses to environmental allergens. Thus, even AD patients diagnosed by the established criteria may have remarkably different backgrounds. When we looked over our published data, we noticed that there were differences in levels of $\operatorname{IgE}$ RAST and skin reactions between AD with atopic respiratory diseases (ARD) and pure AD without ARD. Levels of IgE RAST against airborne allergens, which come into the body mainly through the respiratory tract, were higher in AD with ARD, while those against allergens such as Candida albicans and Malassezia furfur, which can colonize on the skin, were higher in pure AD. In addition to these Th2-mediated immunological abnormalities, Th1-mediated DTH reaction and lymphocyte proliferation indices against airborne allergens were remarkably low in AD with ARD, whereas those against Candida albicans and Malassezia furfur were relatively preserved, although they were lower than those found in normal subjects. We understand from these findings that routes of allergen entry are important for the outcome of the resultant allergic reactions. This point of view is important answering questions such as how AD develops and how it can be prevented from the insults of each allergen. 